\title{
Peran Strategi Diferensiasi dalam Pengaruh Belanja Iklan terhadap Nilai Perusahaan
}

\author{
Prayogo, M. H., Kunaifi, A., dan Wibawa, B. M. \\ Departemen Manajemen Bisnis, Fakultas Teknologi Industri, Institut Teknologi Sepuluh Nopember (ITS) \\ Jl. Arief Rahman Hakim, Surabaya 60111 Indonesia \\ email: m.hafizh12@mhs.ie.its.ac.id
}

\begin{abstract}
Abstrak-Pemilik perusahaan menginginkan nilai perusahaan yang tinggi karena nilai perusahaan yang tinggi mengindikasikan kemakmuran pemegang saham yang tinggi pula. Salah satu cara mengendalikan nilai perusahaan adalah dengan cara mengelola belanja iklan perusahaan. hal tersebut dikarenakan iklan mempunyai pengaruh langsung dan tidak langsung dalam pengambilan keputusan pembelian saham oleh investor. Namun, perusahaan kurang mengetahui mengenai variabel mediasai apa saja dalam pengaruh variabel belanja iklan terhadap variabel nilai perusahaan. Penelitian ini bertujuan untuk mencari tahu peran strategi diferensiasi sebagai variabel moderasi dalam pengaruh belanja iklan terhadap nilai perusahaan. Metode analisis data yang digunakan dalam penelitian ini adalah analisismoderated regression analysis (MRA). Objek amatan penelitian ini adalah perusahaan - perusahaan di Indonesia yang tercatat di Bursa Efek Indonesia. Hasil yang didapat dari penelitian ini adalah belanja iklan berpengaruh positif dan signifikan terhadap nilai perusahaan. strategi diferensiasi berpengaruh positif dan signifikan dalam pengaruh belanja iklan terhadap nilai perusahaan. Namun, terdapat perusahaan yang tidak perlu meningkatkan belanja iklan untuk meningkatkan nilai perusahaannya.
\end{abstract}

Kata Kunci-Belanja Iklan, Moderated Regression Analysis (MRA), Nilai Perusahaan, Strategi Diferensiasi.

\section{PENDAHULUAN}

$\mathrm{I}_{3}$ KLAN memiliki peran yang penting dan membutuhkan biaya $I_{\text {yang banyak, perusahaan dan pemilik saham sangat }}$ memperhatikan efektifitas belanja iklan, terutama berkenaan dengan nilai perusahaan. Penelitian yang dilakukan oleh [9] menemukan bahwa perusahaan yang harga sahamnya turun selama dua kuartil (enam bulan) memiliki kecondongan untuk memutuskan hubungan kerja dengan perusahaan jasa periklanan yang saat ini digunakannya.

Memaksimalkan nilai perusahaan sama dengan memaksimalkan harga saham. Hal tersebut diinginkan pemilik perusahaan karena nilai perusahaan yang tinggi mengindikasikan kemakmuran pemegang saham yang tinggi (Atmaja, 2002, dalam Gultom et al., 2013).

Nilai perusahaan adalah sebuah rasio besarmya total saham suatu perusahaan atas asset yang dimilikinya [14]. Dengan mengetahui rasio tersebut, dapat diketahi apakah penilaian atas suatu perusahaan wajar (rasio sama atau hampir sama dengan 1), berlebihan (rasio diatas 1), atau kurang (rasio dibawah 1). Hal ini berkenaan dengan pendapat [14] bahwa penilaian finansial atas perusahaan atau total saham harus seimbang dengan penilaian nyata atas perusahaan atau total aset. Jika penilaian dinilai berlebihan, maka investasi tambahan layak dilakukan karena perusahaan dinilai dapat dipercaya dan mempunyai aset-aset intangible yang tidak tercantum dalam total aset tercatat. Sebaliknya, jika penilaian dinilai kurang, maka investasi sebaiknya tidak dilakukan.

Salah satu cara untuk mengendalikan nilai perusahaan adalah dengan cara mengelola belanja iklan. Menurut [1] mengemukakan bahwa iklan dapat berpengaruh positif terhadap nilai perusahaan karena pembelian produk dan pembelian saham hampir sama. Individu yang tertarik membeli produk karena iklan komersial juga tertarik membeli saham karena iklan finansial. Temuan tersebut didukung oleh penemuan [3] bahwa investor sering berinvestasi pada hal-

Perusahaan mempunyai kendala dalam mengelola belanja iklan agar berdampak efektif dan positif terhadap nilai perusahaan. Salah satu kendala utama tersebut adalah kurangnya pengetahuan mengenai variabel apa saja yang berada dalam hubungan antara variabel belanja iklan dan variabel nilai perusahaan. Dengan mengetahui variabel apa saja yang berada di antara kedua variabel tersebut, perusahaan dapat mempertimbangkan atau bahkan mengontrol variabel moderasi tersebut untuk mengendalikan efektifitas belanja iklan terhadap nilai perusahaan.

Menurut [10] berpendapat bahwa penelitian adalah jawaban atas kurangnya pengetahuan mengenai variabel moderasi dalam hubungan antara variabel belanja iklan dan variabel nilai perusahaan. Dengan diadakannya penelitian, pihak perusahaan dapat mengetahui alur dampak belanja iklan yang dilakukan terhadap nilai perusahaan. Contohnya adalah penelitian oleh [4] yang telah menemukan adanya hubungan non-linear antara iklan film dan return saham perusahaan bioskop. Hubungan non-linear tersebut diakibatkan oleh pengaruh iklan-iklan film terhadap ekspektasi pelanggan dan pemilik saham yang akhirnya berpengaruh pada harga saham perusahaan bioskop tersebut. akhirnya dapat diketahui bahwa variabel moderasi pada hubungan antara variabel belanja iklan dan variabel nilai perusahaan pada perusahaan bioskop adalah ekspektasi pelanggan dan pemilik saham.

Untuk dapat memenangkan persaingan, dibutuhkan sebuah strategi perusahaan guna menciptakan keunggulan bersaing yang baik (Gartner, 1985). Strategi diferensiasi, yang mengusung keunikan dan keunggulan, terbukti berpengaruh positif dan signifikan terhadap kinerja perusahaan dan kepuasan 
pelanggan (Tai dan Chuang, 2014; Dirisu et al., 2013; Newton, et al. 2015).

Penelitian terdahulu telah menemukan bahwa strategi diferensiasi terbukti berpengaruh kuat dan positif terhadap harga saham perusahaan dan efektifitas belanja iklan terhadap nilai perusahaan [11]. Sayangnya penelitian tersebut dilakukan di Amerika dan penelitian serupa tidak ditemukan di Indonesia. Selain itu, dalam penelitian tersebut, terdapat kesalahan penggunaan indikator strategi perusahaan.

Penelitian ini berusaha membuktikan bahwa strategi diferensiasi mempunyai peran penting dalam pengaruh belanja iklan terhadap nilai perusahaan. Dengan diadakannya penelitian ini, perusahaan - perusahaan dapat mengetahui signifikansi manfaat penggunaan strategi diferensiasi untuk nilai perusahaannya melalui pengelolaan belanja iklan.

\section{LANDASAN TEORI}

\section{Iklan}

Pada tahun 1984, [7] mendefinisikan iklan sebagai "segala bentuk penyajian dan promosi berbayar non-personal berupa ide, barang, atau jasa melalui media massa seperti koran, majalah, televisi, atau radio oleh sponsor yang teridentifikasi". Sedangkan pada tahun 2006, [8] menghapuskan kata-kata "media massa" sehingga definisinya menjadi "segala bentuk penyajian dan promosi berbayar non-personal berupa ide, barang, atau jasa oleh sponsor yang teridentifikasi". Namun, [6], [7], [8] tetap mencamtumkan kata-kata "berbayar" dan "sponsor yang teridentifikasi". Dengan demikian, dapat disimpulkan bahwa iklan semakin tidak terbatas ragamnya tetapi tetap berpacu pada pembayaran oleh sponsor yang teridentifikasi. Oleh karena itu, untuk mengukur usaha-usaha periklanan yang telah dilakukan perusahaan, akan sulit jika harus menghitung iklan-iklan yang telah dimunculkan. Angka belanja iklan merupakan salah satu pilihan terbaik dalam pengukuruan usaha-usaha periklanan yang telah dilakukan perusahaan.

\section{Nilai perusahaan}

Nilai perusahaan adalah sebuah rasio besarmya total saham suatu perusahaan atas asset yang dimilikinya [14]. Pengertian tersebut diuraikan oleh [2] sebagai jumlah nilai saham perusahaan di pasar ditambah jumlah nilai saham preferen perusahaan ditambah hutang perusahaan, baik hutang jangka panjang maupun jangka pendek kemudian semua itu dibagi oleh total aset perusahaan.

Nilai Perusahaan $=\frac{\text { Kapitalisasi Pasar }+ \text { Jumlah Nilai Saham Preferen }+ \text { Hutang }}{\text { Aset Total }}$
Gambar 1 Rumusan Nilai Perusahaan oleh [2]

$\begin{array}{lll}\text { Kapitalisasi Pasar } & = & \text { Jumlah Saham Biasa } \\ \text { Perusahaan } \mathrm{x} \text { Harga Saham }\end{array}$

\section{Strategi diferensiasi}

Strategi diferensiasi adalah usaha untuk menjadi unik pada dimensi-dimensi yang dihargai oleh konsumen di industri tertentu [13].Definisi tersebut merupakan hasil kajian [13] terhadap strategi perusahaan generik usulan [12]. Sedikit berbeda dengan [13], [6] mendefinisikan strategi diferensiasi sebagai konsentrasi perusahaan untuk mencapai kinerja yang unggul pada wilayah manfaat pelanggan yang dinilai penting oleh sebagian besar pasar. Strategi diferensiasi sebaiknya tidak hanya unik tetapi juga unggul dalam manfaat pelanggan yang dinilai penting atau dihargai oleh pelanggan dalam segmen tertentu.

Untuk mengukur strategi diferensiasi yang digunakan oleh perusahaan, indikator strategi diferensiasi Hambrick (1983) digunakan dalam penelitian ini. Indikator tersebut telah digunakan dalam penelitian Berman et al. (1999), Kotha dan Nair (1995), dan [11]. Indikator strategi diferensiasi Hambrick (1983) merupakan rasio belanja iklan dan penjualan perusahaan. semakin besar nilai rasio tersebut, penggunaan strategi diferensiasi di perusahaan tersebut juga semakin tinggi.

$$
\text { Indikator Strategi Diferensiasi }=\frac{\text { Belanja Iklan }}{\text { Total Penjualan }}
$$

Gambar 2 Indikator Strategi Diferensiasi Hambrick (1983)

\section{METODOLOGI PENELITIAN}

\section{A. Hipotesa Penelitian}

Hipotesa yang digunakan dalam penelitian ini dibangun untuk membuktikan ada tidaknya pengaruh strategi diferensiasi dalam hubungan antara belanja iklan dan nilai perusahaan.

$$
\begin{aligned}
\mathrm{H} 1= & \text { Belanja iklan berpengaruh positif terhadap nilai } \\
\text { perusahaan } & \\
\mathrm{H} 2= & \text { Strategi diferensiasi memperkuat pengaruh belanja } \\
& \text { iklan terhadap nilai perusahaan }
\end{aligned}
$$

Spekulasi bahwa belanja iklan akan berpengaruh positif terhadap nilai perusahaan muncul dari kajian literasi penelitian - penelitian terdahulu [11], [10], [4]. Penelitian - penelitian tersebut membuktikan bahwa belanja iklan dan nilai perusahaan mempunyai hubungan yang positif. Spekulasi hipotesa 1 diperkuat oleh penemuan - penemuan Srinivasan et al. (2009), Kirmani dan Wright (1989), dan Mela et al. (1997) bahwa iklan dapat membantu meningkatkan penjualan dan keuntungan di masa depan. Tentunya hal itu membantu meningkatkan ekspektasi investor yang baik terhadap perusahaan. Ekspektasi investor berpengaruh positif terhadap nilai perusahaan [4].

Spekulasi bahwa strategi diferensiasi berpengaruh positif dalam hubungan belanja iklan dan nilai perusahaan muncul dari kajian literasi penelitian [11] bahwa strategi diferensiasi memiliki pengaruh positif yang signifikan dalam hubungan belanja iklan dan nilai perusahaan. Spekulasi hipotesa 2 diperkuat oleh penemuan - penemuan Tai dan Chuang, (2014),Dirisu et al.(2013), danNewton et al. (2015) bahwa strategi diferensiasi berpengaruh positif dan signifikan terhadap kinerja perusahaan dan kepuasan pelanggan.Tentunya hal itu membantu meningkatkan ekspektasi investor yang baik 
terhadap perusahaan. Ekspektasi investor berpengaruh positif terhadap nilai perusahaan [4].

Untuk dapat menguji kedua hipotesa penelitian, dua model regresi berganda moderasian digunakan secara bertingkat. Model regresi tersebut adalah :

1. FirmValue $=a_{0}+b_{1} A E+b_{4}$ Leverage $+b_{5}$ Size + $\mathrm{b}_{6}$ Profit $+\mathrm{e}$

Model ini menjelaskan pengaruh belanja iklan terhadap nilai perusahaan dengan rasio leverage, ukuran perusahaan, dan profitabilitas perusahaan sebagai variabel kontrol.

2. FirmValue $=a_{0}+b_{1} A E+b_{2}(A E x D i f f e r e n t i a t e)+$ $b_{3}$ Differentiate $+b_{4}$ Leverage $+b_{5}$ Size + $\mathrm{b}_{6}$ Profit $+\mathrm{e}$

Model ini menjelaskan pengaruh belanja iklan terhadap nilai perusahaan dengan strategi diferensiasi sebagai variabel moderator dengan rasio leverage, ukuran perusahaan, dan profitabilitas perusahaan sebagai variabel kontrol.

\section{B. Jenis Data}

Data yang digunakan dalam penelitian ini adalah data sekunder yang diperoleh dari Laporan Keuangan Tahunan (LKT) 2015 seluruh perusahaan yang tercatat di Bursa Efek Indonesia (BEI) dan FactBook 2016 BEI. LKT 2015 perusahaan dan FactBook 2016 BEI diperoleh secara online dari situs resmi BEI, yakni www.idx.co.id.

\section{Pengumpulan Data}

Dalam penelitian ini, terdapat enam variabel yang harus dikumpulkan datanya, yakni nilai perusahaan, belanja iklan, indikator strategi diferensiasi, rasio leverage, ukuran perusahaan, dan rasio probabilitas. Variabel nilai perusahaan adalah variabel dependen yang akan diteliti. Variabel belanja iklan dan indikator strategi diferensiasi adalah variabel independen yang akan diteliti. Sedangkan, variabel rasio leverage, ukuran perusahaan, dan rasio probabilitas merupakan variabel kontrol untuk mengontrol efek variabel belanja iklan dan indikator strategi diferensiasi terhadap variabel nilai perusahaan.

Belanja iklan perusahaan dapat diukur dari besar biaya iklan atau biaya promosi yang telah dilakukan oleh perusahaan. Pengukuran nilai perusahaan mencakup pengukuran harga saham perusahaan, jumlah saham biasa dan saham preferen, hutang perusahaan, dan aset lancar dan aset total perusahaan. Pengukuran indikator strategi diferensiasi tersebut mencakup pengukuran belanja iklan dan penjualan perusahaan. Rasio leverage diperoleh dari pembagian aset total perusahaan atas hutang jangka panjang. Ukuran perusahaan ditentukan oleh besarnya aset total perusahaan. Rasio profitabilitas yang digunakan dalam penelitian ini adalah rasio net profit margin. Rasio net profit margin merupakan rasio laba bersih setelah pajak dengan penjualan perusahaan. data - data yang dibutuhkan di atas diperoleh dari LKT 2015 perusahaan dan FactBook 2016 BEI di situs resmi BEI, www.idx.co.id.

Populasi yang digunakan dalam penelitian ini adalah perusahaan-perusahaan terbuka di Indonesia. Sedangkan sampel yang digunakan dalam penelitian ini adalah perusahaanperusahaan terbuka yang terdaftar di Bursa efek Indonesia. Pemilihan sampel ini didasarkan pada purposive sampling.
Tabel 1.

Ringkasan Sampel Penelitian

\begin{tabular}{llr}
\hline \hline No. & \multicolumn{1}{c}{ Deskripsi } & Jumlah \\
1 & $\begin{array}{l}\text { Perusahaan Tercatat di BEI } \\
2\end{array}$ & 537 \\
& $\begin{array}{l}\text { Perusahaan tanpa Laporan Keuangan Tahunan } \\
\text { tersedia di Bursa Efek Indonesia }\end{array}$ & 53 \\
3 & $\begin{array}{l}\text { Perusahaan dengan Laporan Keuangan Tahunan } \\
\text { tersedia di Bursa Efek Indonesia tanpa informasi }\end{array}$ & \\
& $\begin{array}{l}\text { Belanja Iklan } \\
4\end{array}$ & \\
& $\begin{array}{l}\text { Perusahaan dengan Laporan Keuangan Tahunan } \\
\text { tersedia di Bursa Efek Indonesia dengan Informasi }\end{array}$ & \\
& $\begin{array}{l}\text { Belanja Iklan yang tercampur dengan Informasi } \\
\text { Beban selain Belanja Iklan }\end{array}$ & \\
5 & Total Perusahaan Sampel & 319 \\
\hline \hline
\end{tabular}

Analisis pada data terdiri dari analisis deskriptif, normalitas, heteroskedasitas, multikolinieritas, dan regresi linear berganda moderasian bertingkat. Analisis deskriptif dilakukan untuk mengetahui gambaran data yang digunakan dalam penelitian. Analisis normalitas, heteroskedasitas, dan multikolinieritas dilakukan untuk menguji data terhadap asumsi - asumsi yang harus dipenuhi sebelum melakukan analisis regresi. Sedangkan, analisis regresi linear beranda moderasian bertingkat dilakukan untuk mengetahui pengaruh belanja iklan terhadap nilai perusahaan dan peran strategi diferensiasi dalam pengaruh belanja iklan terhadap nilai perusahaan. Uji-T dilakukan untuk mengetahui diterima-tidaknya hipotesa penelitian.

\section{ANALISIS DAN PEMBAHASAN}

\section{A. Analisis Deskriptif}

Analisis deskriptif variabel penelitian meliputi nilai rata-rata, standar deviasi, nilai minimum, dan maksimum masing-masing variabel penelitian. Analisis deskriptif dilakukan untuk mengetahui gambaran data perusahaan sampel penelitian.

Tabel 2.

Analisis Deskriptif Data Sampel Penelitian

\begin{tabular}{lrrrr}
\hline \multicolumn{1}{c}{ Variabel } & Minimum & Maximum & \multicolumn{1}{c}{ Mean } & Std. Deviation \\
\hline FirmValue & $-0,65$ & 37,20 & 1,29 & 3,19 \\
AE & 7,19 & 4.219 .176 & $113.558,88$ & $401.838,10$ \\
Differentiate & $2 \times 10^{-9}$ & 0,29 & 0,02 & 0,04 \\
Leverage & $1,07 \times 10^{-2}$ & 0,98 & 0,25 & 0,26 \\
Size & $42.578,81$ & 910.063 .409 & $21.631 .474,08$ & $7.993 .3918,01$ \\
Profit & $-6,17$ & 45,53 & 0,17 & 2,60 \\
\hline \hline
\end{tabular}

Variabel FirmValue menghasilkan nilai rata-rata sebesar 1,29 dengan standar deviasi 3,19.Temuan ini cukup sesuai dengan nilai perusahaan ideal [14] yang harus mendekati satu. Variabel AE (belanja iklan) perusahaan menghasilkan rata-rata sebesar 113.558,88 (113,6 milyar rupiah) dengan standar deviasi 401.838,10. (401,8 milyar rupiah). 309 perusahaan $(96,8 \%)$ memiliki nilai belanja iklan dibawah rata - rata. Hanya 10 perusahaan $(3,2 \%)$ saja yang belanja iklannya diatas rata rata. Hal ini menunjukan besarnya kesimpangan ukuran belanja iklan yang dilakukan oleh perusahaan - perusahan sampel. Variabel differentiatie menghasilkan rata-rata sebesar 0,020 dengan standar deviasi 0,038 . Nilai variabel differentiate 233 perusahaan $(73 \%)$ dibawah rata - rata. Hal ini menandakan 
banyaknya perusahaan - perusahaan dengan nilai indikator strategi diferensiasi yang kecil. Variabel leverage menghasilkan rata-rata sebesar 0,245 dengan standar deviasi 0,255. 203 perusahaan $(63,6 \%)$ memiliki nilai rasio leverage dibawah rata-rata dan $116(36,3 \%)$ perusahaan memiliki nilai rasio leverage diatas rata-rata. Sebaran variabel ini cukup normal dibandingkan sebaran variabel - variabel sebelumnya. Variabel size menghasilkan rata-rata sebesar 21.631.474,08 (21,6 triliun rupiah) dengan standar deviasi 79.933.918,01 (79,9 triliun rupiah). Terdapat 271 perusahaan $(84,9 \%)$ dengan nilai ukuran perusahaan dibawah rata - rata dan 48 perusahaan $(15,1 \%)$ dengan nilai ukuran perusahaan diatas rata - rata. Hal ini disebabkan oleh banyaknya perusahaan sampel yang mempunyai nilai ukuran perusahaan kecil. Variabel profit menghasilkan rata-rata sebesar 0,176 dengan standar deviasi 2,602. Terdapat 234 perusahaan $(73,3 \%)$ dengan nilai profitabilitas dibawah rata - rata dan 85 perusahaan $(26,6 \%)$ dengan nilai profitabilitas diatas rata - rata. Sebaran variabel ini akan cukup rata jika perusahaan dengan nilai profitabilitas tertinggi, yakni PT Indoritel Makmur Internasional Tbk. dengan nilai probabilitas 45,53 , dan perusahaan dengan nilai profitabilitas terendah, yakni PT Mitra Investindo Tbk. dengan nilai probabilitas $-6,17$, dikeluarkan dari kumpulan sampel perusahaan.

\section{B. Uji Asumsi}

Untuk dapat melakukan analisis regresi yang valid dan reliabel, perlu dilakukan uji asumsi terlebih dahulu. Uji asumsi tersebut meliputi uji normalitas, uji heteroskedastisitas, dan uji multikolinieritas.

Uji Normalitas bertujuan untuk menguji apakah dalam model regresi, variabel pengganggu atau residual memiliki distribusi normal. Pengujian normalitas dilakukan dengan menggunakan normal probability plot dan uji kolmogorov smirnov.
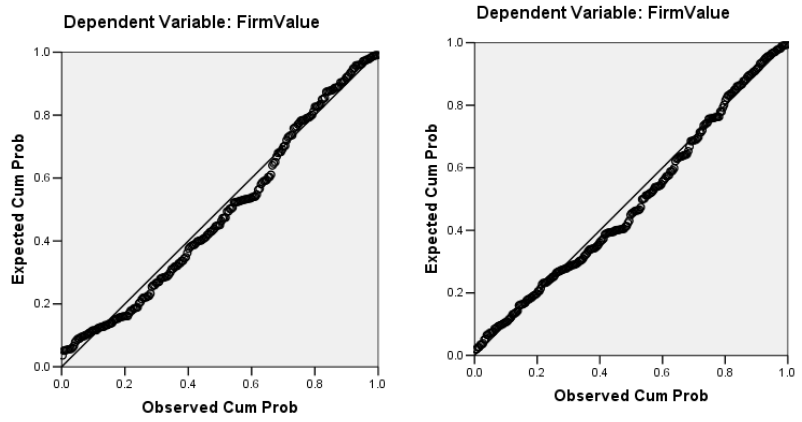

Gambar 3. Normal Probability Plot Regresi Pengaruh Belanja Iklan terhadap Nilai Perusahaan (kiri) dan Pengaruh Belanja Iklan terhadap Nilai Perusahaan dengan Strategi Diferensiasi sebagai variabel moderasi (kanan).

Uji normal probability plot menunjukkan bahwa titik-titik terkumpul di sekitar garis normal, sehingga disimpulkan residual model regresi mengikuti distribusi normal. Sedangkan, hasil pengujian kolmogorov smirnov pada 319 sampel menunjukkan distribusi data yang tidak normal dengan nilai signifikansi sebesar 0,000 atau lebih kecil dari 0,05. Oleh sebab itu, dilakukan proses pereduksian outlier melalui proses analisis casewise diagnostics. Jumlah sampel penelitian kemudian berubah dari 319 menjadi 243 untuk model regresi hipotesa 1 dan 244 untuk model regresi hipotesa 2. Dengan dilakukannya preduksian outlier, hasil signifikansi pengujian kolmogorov smirnov mengalami perubahan, seperti dijelaskan pada tabel 3.

Tabel 3.

Uji Normalitas dengan Kolmogorov Smirnov

\begin{tabular}{llll}
\hline \hline Model Regresi & \multicolumn{1}{c}{ Jumlah Sampel } & $\begin{array}{c}\text { Nilai } \\
\text { Signifikansi }\end{array}$ & Keterangan \\
\hline Model Regresi & Awal (N=319) & 0,000 & Tidak Normal \\
Hipotesa 1 & $\begin{array}{l}\text { Setelah reduksi } \\
\text { outlier (N=243) }\end{array}$ & 0,076 & Normal \\
Model Regresi & Awal (N=319) & 0,000 & Tidak Normal \\
Hipotesa 2 & $\begin{array}{l}\text { Setelah reduksi } \\
\text { outlier (N=244) }\end{array}$ & 0,122 & Normal \\
\hline
\end{tabular}

Tabel 4.

Uji Heteroskedasitas dengan Gletzer Test

\begin{tabular}{|c|c|c|c|}
\hline Model Regresi & $\begin{array}{c}\text { Variabel } \\
\text { Independen }\end{array}$ & $\begin{array}{l}\text { Signifi- } \\
\text { kansi }\end{array}$ & Keterangan \\
\hline \multirow{10}{*}{$\begin{array}{l}\text { Model Regresi } \\
\text { Hipotesa } 1\end{array}$} & $\mathrm{AE}(\mathrm{N}=243)$ & 0,415 & Non \\
\hline & & & Heteroskedasitas \\
\hline & $\mathrm{AE}(\mathrm{N}=233)$ & 0,502 & Non \\
\hline & & & Heteroskedasitas \\
\hline & $\begin{array}{l}\text { Leverage } \\
(\mathrm{N}=243)\end{array}$ & 0,006 & Heteroskedasitas \\
\hline & $\begin{array}{l}\text { Leverage } \\
(\mathrm{N}=223)\end{array}$ & 0,898 & $\begin{array}{l}\text { Non } \\
\text { Heteroskedasitas }\end{array}$ \\
\hline & Size $(\mathrm{N}=243)$ & 0,868 & $\begin{array}{l}\text { Non } \\
\text { Heteroskedastisitas }\end{array}$ \\
\hline & $\operatorname{Size}(\mathrm{N}=223)$ & 0,854 & $\begin{array}{l}\text { Non } \\
\text { Heteroskedastisitas }\end{array}$ \\
\hline & Profit $(\mathrm{N}=243)$ & 0,176 & $\begin{array}{l}\text { Non } \\
\text { Heteroskedastisitas }\end{array}$ \\
\hline & $\operatorname{Profit}(\mathrm{N}=223)$ & 0,209 & $\begin{array}{l}\text { Non } \\
\text { Heteroskedastisitas }\end{array}$ \\
\hline \multirow{7}{*}{$\begin{array}{l}\text { Model Regresi } \\
\text { Hipotesa } 2\end{array}$} & $\mathrm{AE}(\mathrm{N}=244)$ & 0,507 & Non \\
\hline & & & Heteroskedastisitas \\
\hline & $\begin{array}{l}\text { Differentiate } \\
(\mathrm{N}=244)\end{array}$ & 0,074 & $\begin{array}{l}\text { Non } \\
\text { Heteroskedastisitas }\end{array}$ \\
\hline & $\begin{array}{l}\text { Leverage } \\
(\mathrm{N}=244)\end{array}$ & 0,108 & $\begin{array}{l}\text { Non } \\
\text { Heteroskedastisitas }\end{array}$ \\
\hline & Size $(\mathrm{N}=244)$ & 0,945 & $\begin{array}{l}\text { Non } \\
\text { Heteroskedastisitas }\end{array}$ \\
\hline & Profit $(\mathrm{N}=244)$ & 0,234 & $\begin{array}{l}\text { Non } \\
\text { Heteroskedastisitas }\end{array}$ \\
\hline & $\begin{array}{l}\text { AE*Differentiate } \\
(\mathrm{N}=244)\end{array}$ & 0,580 & $\begin{array}{l}\text { Non } \\
\text { Heteroskedastisitas }\end{array}$ \\
\hline
\end{tabular}

Hasil dari gletzer test setelah pengurangan outlier menunjukkan bahwa nilai signifikansi masing-masing variabel bebas pada kedua model regresi lebih besar dari $0,05(\alpha=5 \%)$. Dengan demikian, dapat disimpulkan bahwa asumsi tidak adanya heteroskedastisitas pada kedua model regresi terpenuhi.

Uji Heterokedastisitas digunakan untuk menguji sama atau tidaknya varian antara residual observasi satu dengan yang lainnya. Model regresi yang baik tidak mengandung heteroskedastisitas, dengan kata lain varian residual harus homogen. Pendeteksian ada atau tidaknya heteroskedastisitas dilakukan dengan metode gletzer test, yaitu meregresikan variabel bebas terhadap nilai absolute residual (Glejser, 1969 dalam Berry \& Feldman, 1985). Pengujian heteroskedasitas mereduksi sampel dengan Z-score pada model regresi hipotesa 1 sebanyak 20 sehingga menjadi 223 dari sampel uji normalitas model regresi 1 yang sebanyak 243. Sedangkan, sampel pada model regresi hipotesa 2 tetap sebanyak 244. 
Multikolinieritas merupakan suatu keadaan dimana di antara variabel bebas dalam model regresi terdapat hubungan atau korelasi yang tinggi. Model regresi yang baik adalah yang tidak mengandung multikolinieritas. Untuk mendeteksi ada tidaknya multikolinieritas digunakan Variance Inflation Factor (VIF), apabila nilai tolerance lebih besar dari 0,10 atau nilai VIF kurang dari 10, maka tidak ada multikolinieritas antar variabel bebas dalam model regresi. Berdasarkan tabel 5, dapat diketahui bahwa nilai tolerance masing-masing variabel bebas pada kedua model regresi di atas angka 0,10 , demikian pula nilai VIF semua variabel dibawah angka 10, sehingga dapat disimpulkan bahwa kedua model regresi bebas dari multikolinieritas.

Tabel 5.

Uji Multikolinieritas

\begin{tabular}{|c|c|c|c|c|}
\hline Model Regresi & $\begin{array}{c}\text { Variabel } \\
\text { Independen }\end{array}$ & Tolerance & VIF & Keterangan \\
\hline \multirow[t]{4}{*}{$\begin{array}{l}\text { Model Regresi } \\
\text { Hipotesa } 1\end{array}$} & $\mathrm{AE}$ & 0,797 & 1,254 & $\begin{array}{l}\text { Non Multiko- } \\
\text { linieritas }\end{array}$ \\
\hline & Leverage & 0,846 & 1,181 & $\begin{array}{l}\text { Non Multiko- } \\
\text { linieritas }\end{array}$ \\
\hline & Size & 0,704 & 1,421 & $\begin{array}{l}\text { Non Multiko- } \\
\text { linieritas }\end{array}$ \\
\hline & Profit & 0,997 & 1,003 & $\begin{array}{l}\text { Non Multiko- } \\
\text { linieritas }\end{array}$ \\
\hline \multirow[t]{6}{*}{$\begin{array}{l}\text { Model Regresi } \\
\text { Hipotesa } 2\end{array}$} & $\mathrm{AE}$ & 0,118 & 8,502 & $\begin{array}{l}\text { Non Multiko- } \\
\text { linieritas }\end{array}$ \\
\hline & Differentiate & 0,911 & 1,097 & $\begin{array}{l}\text { Non Multiko- } \\
\text { linieritas }\end{array}$ \\
\hline & Leverage & 0,890 & 1,123 & $\begin{array}{l}\text { Non Multiko- } \\
\text { linieritas }\end{array}$ \\
\hline & Size & 0,556 & 1,800 & $\begin{array}{l}\text { Non Multiko- } \\
\text { linieritas }\end{array}$ \\
\hline & Profit & 0,996 & 1,004 & $\begin{array}{l}\text { Non Multiko- } \\
\text { linieritas }\end{array}$ \\
\hline & $\begin{array}{l}\mathrm{AE}^{*} \\
\text { Differentiate }\end{array}$ & 0,127 & 7,845 & $\begin{array}{l}\text { Non Multiko- } \\
\text { linieritas }\end{array}$ \\
\hline
\end{tabular}

C. Analisis regresi linear berganda moderasian bertingkat

Analisis regresi linier berganda dilakukan untuk mengetahui pengaruh pada variabel bebas terhadap variabel terikat. Koefisien regresi belanja iklan sebesar 0,397 menunjukkan bahwa belanja iklan mempunyai pengaruh positif terhadap nilai perusahaan. Jadi semakin tinggi nilai belanja iklan perusahaan maka semakin tinggi nilai perusahaan. Uji t yang ditunjukkan oleh analisis regresi SPSS menunjukkan bahwa nilai t hitung belanja iklan terhadap nilai perusahaan $(5,619)$ lebih tinggi daripada $t$ tabel $(2,257)$ dengan df sebesar 218 dan $\alpha / 2$ sebesar 0,025 . Nilai signifikansi yang ditunjukkan oleh analisis regresi SPSS adalah 0,000 atau sangat kecil sekali dan bernilai lebih rendah dari 0,05 . Nilai $t$ hitung yang lebih besar dari $t$ tabel dan nilai signifikansi yang lebih kecil dari 0,05 membuat hipotesa 1 diterima. Berdasarkan hasil tersebut, hipotesis 1 yang menyatakan bahwa belanja iklan memiliki pengaruh positif terhadap nilai perusahaan terbukti kebenarannya.

Tabel 6.

Analisis Regresi Linear Berganda

\begin{tabular}{lllll}
\hline \hline \multicolumn{1}{c}{ Model } & Variabel & $\begin{array}{c}\text { Koefisien } \\
\text { Standardized }\end{array}$ & T Hitung & \multicolumn{2}{c}{ Signifikansi } \\
Regresi & & \multicolumn{2}{c}{ (Unstandardized) } & \\
\hline Model & Intersep & 0,409 & Signifi-
\end{tabular}

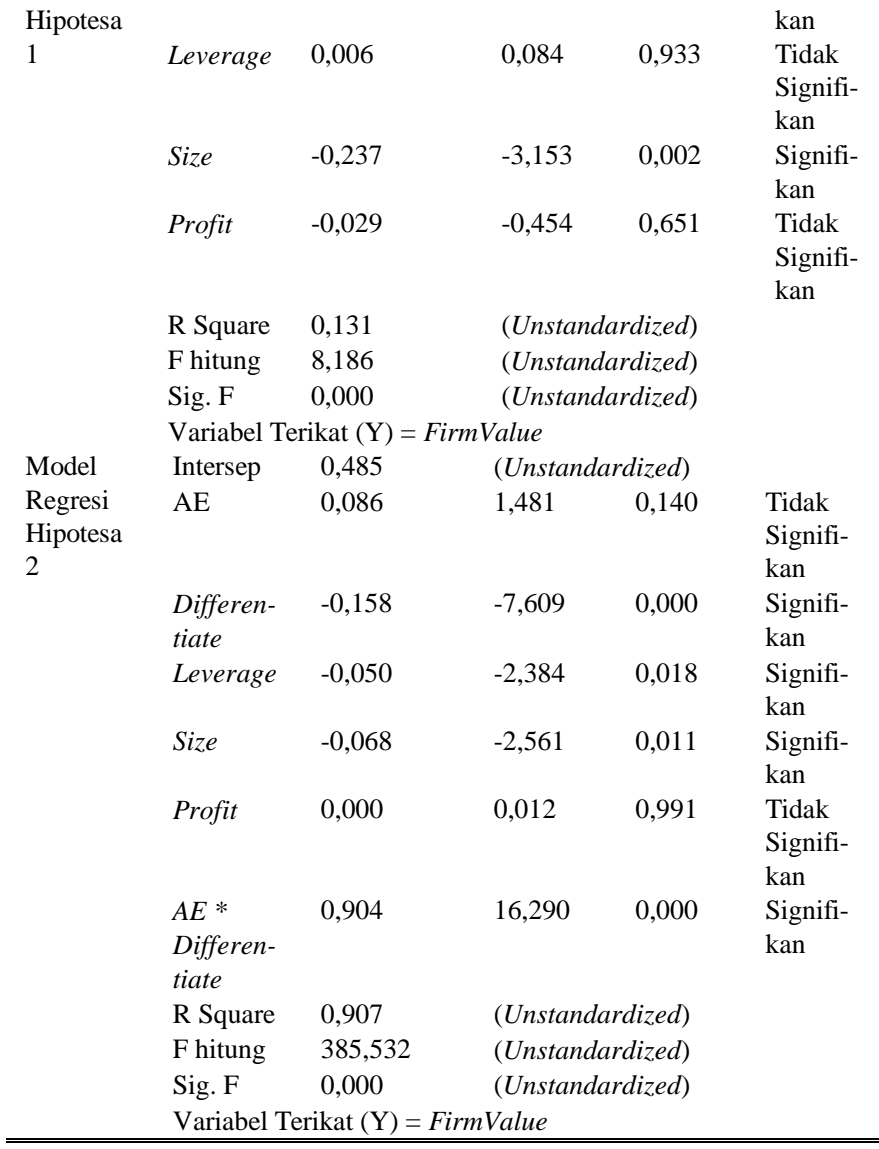

Penerimaan hipotesa 1 membuktikan bahwa belanja iklan mempunyai pengaruh positif terhadap nilai perusahaan perusahaan - perusahaan di Indonesia. Semakin besar anggaran belanja iklan perusahaan, semakin besar nilai perusahaan yang akan diperoleh oleh perusahaan. Temuan ini mendukung temuan penelitian [11] dan [10] bahwa belanja iklan memiliki pengaruh positif terhadap nilai perusahaan. Temuan ini juga secara tidak langsung mendukung pernyataan [1] bahwa iklan dapat berpengaruh positif terhadap nilai perusahaan karena pembelian produk dan pembelian saham hampir sama. Individu yang tertarik membeli produk karena iklan komersial juga tertarik membeli saham karena iklan finansial. Ketidaksesuaian pada hipotesis 1 ditemukan pada beberapa perusahaan sampel. Terutama PT. Inti Agri Resources Tbk., yang memiliki nilai perusahaan tertinggi $(37,2)$ dan hanya memiliki anggaran belanja iklan yang kecil (delapan juta rupiah). Tampaknya, hal ini disebabkan oleh koefisien determinasi yang kecil, yakni 0,131 , sehingga model regresi hanya bisa mencakup 13,1\% sampel. Koefisien determinasi yang kecil menandakan bahwa terdapat variabel - variabel lain yang perlu dimasukkan ke dalam model. Hasil ini cocok dengan salah satu tujuan dilakukannya penelitian ini, yakni menemukan peran variabel moderator dalam pengaruh belanja iklan terhadap nilai perusahaan.

Koefisien regresi variabel moderasi strategi diferensiasi dalam pengaruh belanja iklan terhadap nilai perusahaan (AE*Differentiate) adalah sebesar 0,904 menunjukkan bahwa variabel tersebut mempunyai pengaruh positif terhadap nilai perusahaan. Semakin tinggi belanja iklan yang dipengaruhi oleh 
strategi diferensiasi, semakin tinggi pula nilai perusahaan. Uji t yang ditunjukkan oleh analisis regresi program SPSS menunjukkan bahwa nilai $\mathrm{t}$ hitung variabel moderasi AE*Differentiate $(16,29)$ lebih besar daripada nilai $t$ tabel (2,255) dengan df sebesar 237 dan $\alpha / 2=0,025$. Berdasarkan hasil tersebut, hipotesis 2 yang menyatakan bahwa strategi diferensiasi memperkuat pengaruh belanja iklan terhadap nilai perusahaan terbukti benar.

Penerimaan hipotesa 2 membuktikan bahwa strategi diferensiasi memperkuat pengaruh belanja iklan terhadap nilai perusahaan perusahaan - perusahaan di Indonesia. Belanja iklan akan lebih berdampak terhadap nilai perusahaan jika strategi diferensiasi lebih banyak digunakan. Temuan ini mendukung penelitian [11] bahwa strategi diferensiasi mempunyai pengaruh positif dalam hubungan belanja iklan dan nilai perusahaan.

Kenaikan nilai koefisien determinasi dari model regresi pengaruh belanja iklan terhadap nilai perusahaan $(0,13)$ pada model regresi moderasi strategi diferensiasi dalam pengaruh belanja iklan terhadap nilai perusahaan $(0,907)$ menandakan bahwa penelitian ini berhasil menemukan variabel moderator yang berperan positif dan signifikan dalam pengaruh belanja iklan terhadap nilai perusahaan.

\section{V.SIMPULAN}

Penelitian ini bertujuan untuk mengetahui pengaruh belanja iklan terhadap nilai perusahaan pada perusahaan - perusahaan di Indonesia secara keseluruhan. Hal ini dimaksudkan agar penelitian ini dapat membuat gambaran umum mengenai pengaruh belanja iklan terhadap nilai perusahaan perusahaan perusahaan di Indonesia.

Secara umum, belanja iklan berpengaruh positif dan signifikan terhadap nilai perusahaan perusahaan - perusahaan di Indonesia. Strategi diferensiasi dapat meningkatkan pengaruh belanja iklan terhadap nilai perusahaan. Temuan ini, mengisyaratkan perusahaan agar menggunakan strategi diferensiasi dalam mengiklankan perusahaannya agar investor tertarik dengan perusahaan.

West et al. (2008, dalam [10] menyatakan bahwa kreatifitas dalam periklanan sangat dihargai atas kemampuannya memperoleh perhatian konsumen dan menanamkan value kepada brand. Penggunaan kreatifitas untuk penanaman value tersebut hendaknya berdasarkan karakter - karakter diferensiasi yang dimiliki oleh perusahaan, sehingga iklan punya karakter khusus yang mudah diingat dan asosiatif dengan perusahaan.

Penelitian ini berhasil menemukan peran variabel strategi diferensiasi dalam pengaruh belanja iklan terhadap nilai perusahaan. Temuan ini merupakan bentuk sumbangan dalam usaha peneliti - peneliti dunia untuk menemukan variabel variabel moderator pengaruh belanja iklan terhadap nilai perusahaan [4], [5], [10], [11]. Penelitian - penelitian mengenai variabel moderasi tersebut pada akhirnya dilakukan untuk menemukan rumusan pasti atas pengaruh belanja iklan terhadap nilai perusahaan.

\section{DAFTAR PUSTAKA}

[1] Boyd, J. H., \& Schonfeld, E. P. (1977). The Effect of Financial Press Advertising on Stock Prices. Financial Management, 6 (2), 42-51.

[2] Chung, K. H., \& Pruitt, S. W. (1994). A Simple Approximation of Tobin's $q$. Financial Management, 23, 70-74.

[3] Huberman, G. (2001). Familiarity Breeds Investment. The Review of Financial Studies, 14 (3), 659-680.

[4] Joshi, A., \& Hanssens, D. M. (2009). Movie Advertising and the Stock Market Valuation of Studios: a Case of "Great Expectations" ? Marketing Science, 82 (2), 239-250.

[5] Joshi, A., \& Hanssens, D. M. (2010). The Direct and Indirect Effects of Advertising Spending on Firm Value. Journal of Marketing, 74 (1), 2033.

[6] Kotler, P. (2005). Manajemen Pemasaran, Jilid 1. Jakarta: Indeks.

[7] Kotler, P. (1984). Marketing Essentials. Northwestern University: Prentice-Hall,Inc.

[8] Kotler, P., \& Amstrong, G. (2006). Principles of Marketing. New Jersey: Pearson Prentice-Hall.

[9] Kulkarni, M., Vora, P., \& Brown, T. (2003). Firing Advertising Agencies : Possible Reasons and Managerial Implications. Journal of Advertising, 32 (3), $77-86$.

[10] Luo, X., \& de jong, P. J. (2012). Does Advertising Spending Really Work ? The Intermediate Role of Analysts in the Impact of Advertising on Firm Value. Journal of the Academy of Marketing Science, 40 (4), 605624.

[11] McAlister, L., Srinivasan, R., Jindal, N., \& Canella, A. A. (2016). Advertising Efectiveness : The Moderating Effect of Firm Strategy. Journal of Marketing Research, 53 (2), 207-224.

[12] Porter, M. E. (1985). Competitive Advantage. New york: Free Press.

[13] Tanwar, R. (2013). Porter's Generic Competitive Strategies. IOSR Journal of Business and management, 15 (1), 11-17.

[14] Tobin, J. (1969). A General Equilibrium Approach To Monetary Theory. Journal of Money, 1 (1), 15-29. 